\title{
EDUCATION IN COMMUNITY ARCHIVES: THE KARTA CENTRE AND THE GENERAL ELŻBIETA ZAWACKA FOUNDATION ${ }^{19}$
}

\author{
MAGDALENA WIŚNIEWSKA-DREWNIAK \\ Faculty of History, Nicolaus Copernicus University, \\ ul. Bojarskiego 1, Torun, Poland \\ E-mail address: magwis@doktorant.umk.pl
}

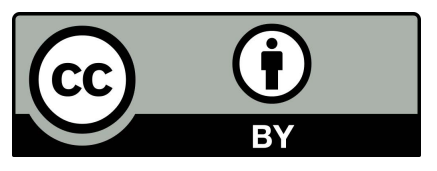

\section{ABSTRACT}

In general, community archives are grass-roots documentary initiatives built around a broadly defined community, which collect, preserve, describe and provide access to historical sources concerning a previously chosen topic, e.g. local history and traditions, a social movement, a minority, an ethnic group, an event or a person. The phenomenon of community archiving is not new, but only several years ago it started to be described by scholars in Poland.

The article describes educational activities performed by two of the biggest and most influential community archives in Poland: the KARTA Centre Foundation in Warsaw and the General Elżbieta Zawacka Foundation in Torun. Actions of these archives are shown referring to general understanding of education in historical archives, as well as the specific situation of Polish archives, especially their mission to promote historical knowledge and local identity. Also promotional qualities of educational endeavours in archives are stressed.

Key words: community archives; the KARTA Centre Foundation; the General Elżbieta Zawacka Foundation; education in archives

\section{INTRODUCTION}

In general, community archives are grass-roots documentary initiatives built around a broadly defined community, which collect, preserve, describe and provide access to historical sources concerning a previously chosen topic, e.g. local history and traditions, a social movement, a minority, an ethnic group, an event or a person. The phenomenon of community archiving is not new, but only several years ago it started to be described by scholars in Poland. There are probably several hundreds of community archives that currently operate in Poland. Many of them are well engaged and deeply rooted in local communities and have big impact on the local cultural life. The purpose of this article is to describe some educational activities conducted by two of the big-

19 The research project is funded by the National Science Centre, Poland/Narodowe Centrum Nauki; grant No. 2015/19/N/HS3/02466. 
gest, most influential and best known Polish community archives: the KARTA Centre Foundation in Warsaw and the General Elżbieta Zawacka Foundation in Torun. Actions of these archives will be shown referring firstly to the general understanding of education in archives. There are many examples of academic analysis of educational activities of state archives in Poland, but very little about such endeavours of community archives. This situation will be probably changing in the near future in consequence of growing interest of archival science in Poland in the phenomenon of grass-roots archiving, especially due to the fact that community archives are growing in strength and are playing an increasingly important role among historical archives and other cultural institutions.

This article is based mostly on literature review and analysis of on-line content concerning educational activities of the two above mentioned community archives. In consequence, not all educational actions of these archives has been mentioned here. Moreover, the two chosen archives cannot be seen as true representatives of the grass-roots documentary movement. Community archives may vary significantly, in size, in topic, in actions taken, in ways of management or in ways of conducting their archival functions. The two described foundations are the biggest community archives in Poland, but most community archives are small initiatives, run by few persons, with very little or no funds, formal employees, or storage space.

This article also aims at raising awareness about educational activity of community archives, as well as encouraging studying community archives and their educational endeavours, also using more detailed methods, especially those rooted in social sciences, like interviews and observations.

\section{ARCHIVES AND EDUCATION}

For the purposes of this article the term "educational activity" will be used very broadly, not only as methods used in school and school-like environments, but as all means aiming at increasing knowledge, experience, and attitudes in members of society, using some educational actions. This approach is successfully used by scholars while writing about educational activity of historical archives in Poland (Rosa, 2012, p. 34). In consequence, "archival education" refers to all educational activity performed by archives and aimed at schools and pupils/students, as well as endeavours pursued to participate in supporting long-life learning. The audience of archival education may be broad - pupils and students, teachers, genealogists, history lovers, scholars, journalists, organisers of cultural events, archivists and office workers, and, in general, all members of society. Naturally, methods used in and topics covered by educational activities of archives will depend on their recipients. But the most common methods and forms of education used by archives in Poland are: archival exhibitions, archival workshops, conferences, courses, archival lessons, talks, discussions, demonstrations, lectures, games, competitions, and 
so called archival tourism. All education forms and methods used by archives were described in a vast study of Agnieszka Rosa (2012, pp. 181-250).

The educational activity of archives is strictly connected to promoting archives. In theory, two types of activity of historical archives might be distinguished. The purpose of archival education is to influence knowledge and attitudes without intention to be given any feedback. On the other hand actions promoting archives are taken to receive some positive response from the society; in consequence archivist wishes that someone will become an archives user or will engage in the archives' life. Practically these two spheres are not easy to separate, especially due to the fact that proper educational endeavours can have very good influence on social reception of the particular archive or archives in general (Chorążyczewski, 2008, p. 52).

Educational activity around archives can create or enhance historical awareness and historical culture, belief that the past is important and history is a crucial element of culture and ingredient of identities. Archives can intentionally shape knowledge and social attitudes, like patriotism, not only in the national, but also in the local variant, through organising educational events aimed at local or regional history. Education can also be the key to creating so called documentation culture. On the one hand, it lies in making archives' users more aware of what archives exist and what they store, how one searches information in archives, and how one behaves in archives. It is a form of educating future users and, in consequence, making it easier in the future for archivists to serve them. On the other hand, these actions can promote the "pro-documentation" attitude - respect for records and some kind of responsiveness to traces of the past. Moreover, archival education may also promote archives as memory institutions that play an important role in the democratic information society (Chorążyczewski, 2008, p. 52; Rosa, 2012, p. 34).

\section{WHAT ARE COMMUNITY ARCHIVES AND WHY THEY EDUCATE?}

It is not easy, neither for scholars, nor for practitioners, to agree on the definition of community archives, and it is not only the case in Poland, but all over the world (Flinn, 2007, pp. 152-154; Flinn, 2011, pp. 5-8; Gilliland, \& Flinn, 2013, pp. 2-11). The most important quality of community archives is indicated in academic understanding of the term is their connection to a community. This community might be defined very broadly: as a geographical community, a group of people who live in the same place or location, but also communities defined genetically or socially (families), as well as according to some culture, ethnicity, race, background (Welland, 2015, p. 9) or thematic interest (Norgrove, Mirchandani, \& Goddard, 2008, p. 3). Community archives are collections of archival records created by such a community. Archival records are records of organisations and individuals selected for 
indefinite preservation due to their enduring value (Maciejewska, 1974, p. 51; Pearce-Moses, 2005, p. 28). Terms corresponding with "community archive" are, among others, independent archive, autonomous archive, ethnic archive (Flinn, 2011, p. 6).

Currently in Poland there are, dependent on varying understanding of the term, several hundreds of community archives (Ziętal, 2014, p. 72). Most of them are run by NGOs, but there are also those created by informal groups or individuals. They vary significantly due to their size, activities, cooperation with other institutions and initiatives, and types of collected materials. Among those materials are especially photographs, diaries, oral history testimonies, personal documents, correspondence, and ephemera, but it is a common situation that such an archive collects also museum artefacts and printed materials, and thus it combines functions of the archive, museum, and library.

Community archives are not institutions created to preserve legal records or to provide support in managing an organisation. Community archives have their mission: on the one hand, preservation of traces of the past, on the other, spreading knowledge on a particular event, period of time, person, or place according to a topic chosen by the archive. This purpose can be achieved by the archives' educational activity. Thanks to that community archives can fulfil their mission: spread history knowledge and civic duty awareness, strengthen local, ethnic or any other identities - according to the archive's statute or any other, less formalised objectives.

But the effort put in educational endeavours may result also in different ways - due to the above mentioned connection between education and promotion of archives. Community archives cannot underestimate this fact. They are more dependent on society than, for example, state archives, funded from national budgets. They need archival materials donated by members of the society, need their voluntary work, financial donations or any other kind of help and support. Moreover, engagement in the life of the society through educational actions might very positively influence reception of the community archive by other institutions, like schools, local authorities, NGOs; thanks to that it may be easier to start cooperating with them or to receive some kind of support in the future. Therefore educational activity, serving also as promotion, can be, and is, an important part of community archives' lives.

It is worth to further describe the issue of teaching pro-documentary awareness. In the question of collecting archival materials, community archives frequently depend on donors and their old letters taken out of drawers, photographs from their old albums, diaries that had been lying in boxes in the bottom of a basement. Hence important parts of educational activity of community archiving should be rising awareness on creating personal archives and keeping traces of the past, as well as basic standards of storage of old documents (Strzelecka, 2007, p. 116). 


\section{THE KARTA CENTRE}

The KARTA Centre Foundation, situated in Warsaw, is the biggest Polish community archive. Formerly the foundation was created in the 1990s, but it started its work undercover in the 1980s, during the communist rule in Poland (Gluza, 2006). Its holdings comprise over 1.400 metres of archival and library collections, 180.000 photographs and over 5.000 audio recordings. The archival holdings consist of four main parts: the Eastern Archive (1901-1956), which comprises materials concerning Poland regaining independence after the Great War, the mid-war period, the Second World War, and the period of Stalinism, especially repressions of the USSR on the Poles between 1939 and 1956; the Opposition Archive (1956-1990) that documents the Polish resistance movement against the communism and social life in the period of the Polish People's Republic; the Photo Archive, which consists of images from the whole 20th century, sometimes even from last decades of the 19th century; and the Oral History Archive, which collects interviews with witnesses of the 20th-century history, especially the passing generation (Gluza, 2012a, p. 27).

Among numerous actions organised by the KARTA Centre, educational endeavours have their special place. It is not an easy task to describe all educational activities taken by the KARTA, and here I will present only a selection of them.

Some of the most important undertakings of the KARTA Centre are research competitions entitled Historia Bliska [The Close History], organised for pupils of middle schools and high schools. The first edition of the competition was organised in 1996, in 2017 the KARTA prepares the 20th edition of it. Participants of these competitions present research work that fits the particular year's general topic of the competition; previous years topics were, among others, Everyday life in Poland 1945-56, Family in the history whirl, Work in the Polish People's Republic: for oneself, for the society, for the system?, The rebellious of the 20th century, The stigma of the Second World War: fate and remembrance (Gluza, 2012b, pp. 360-362). Seventeen editions of the competition that were organised between 1996 and 2013 had almost 14.000 authors; almost 8.000 works were sent to the KARTA Centre (Ośrodek KARTA).

The works of the KARTA Centre include also numerous archival exhibitions, organised since the beginning of the 1990s. These exhibitions covered various topics, for example: Polish refugees in Romania, Dementi. Independent Photo Agency 1982-1991, Rejecting a lie. The history of resistance and anti-totalitarian opposition in the 20th century, Gates of freedom. From »Solidarity « to the German reunification, The end of Yalta, Small business owners 1945-1989, Warsaw. May 1926, The route to self-government 1916-1990, Cyclists. Sympathizers, Fiends, Masters. The KARTA's exhibitions have been displayed in various locations, not only in Poland, but also abroad. Many of these archival exhibitions were created in cooperation with a variety of institutions and organisations, like Kreisau Initiative - Berlin, Polish Ministry of External Affairs, Representatives of the European Commission in Poland, University of Warsaw, Consulate-General 
of the Polish Republic in New York, and Embassy of the Polish Republic in the Lithuanian Republic (Gluza, 2012b, pp. 363-367).

During the past few years the KARTA Centre has been putting much effort into consolidating the Polish movement of community archiving and creating its network. These endeavours have also a part concerning educating community archivists on how to create and manage their archives, store them, collect, arrange, and describe their materials, digitise sources, record oral histories, run the archive's website, and much more. A manual for community archivists has been published (Ziętal, 2012), as well as other materials, available on-line on the portal for community archives www.archiwa.org. The KARTA also has been organising stationary and on-line courses for community archivists.

The KARTA Centre conducts also other forms of educational activity. It runs various educational websites, for example: Uczyć się z historii (eng. Learning from history) (www.uczyc-sie-z-historii.pl), a part of international education network Learning from history, a platform for sharing educational projects on the history of Poland and its neighbours in the 20th century, especially the experience of two totalitarianisms: Nazism and communism; XX wiek (eng. The 20th century) (www.xxwiek.pl), a website that presents the 20th-century history through an axis of time with various source materials: testimonies, diaries, audio and video recordings, ephemera; Rok 1945. Między wojng a podległościa/1945 (eng. Between war and dependence) (www.1945.karta.org. pl), containing source materials, photo gallery and a calendar of the year 1945 . Another interesting form of education is so called "archival tourism" - shortterm tourist events organised to visit places, described in archival sources, that have some material and nonmaterial values (Rosa, 2012, p. 198). The KARTA Centre engaged in creating a project $U$ aktorek (eng. At the actresses) (www. uaktorek.pl) about artistic cafés in Warsaw between 1939 and 1944. The website proposes several tourist routes based on the history of the artistic life during the time of the Nazi occupation and presents archival and printed sources to the topic. The KARTA Centre also organises debates, conferences, workshops, and other meetings concerning various topics of the most recent history and community archiving.

\section{THE ELŻBIETA ZAWACKA FOUNDATION}

The General Elżbieta Zawacka Foundation: the Pomeranian Archive and Museum of the Home Army and Polish Women's Military Service is situated in Torun and is the second biggest and most influential community archive in Poland. The Foundation legalised its activity after the political turn in 1989/1990, but Elżbieta Zawacka started her archival endeavours in the 1960s. General Elżbieta Zawacka was born in 1909. During the Second World War she was a courier from occupied Poland, a soldier trained in the West, the only woman parachuted over Nazi-occupied Poland to join the resistance forces, and the Warsaw Uprising (1944) soldier (Minczykowska, 2014, pp. 69-160). 
From the 1960s Elżbieta Zawacka collected materials on three main topics: the history of conspiracy in Pomerania (the northern part of Poland), the military service of Polish women, and the history of the Department of Foreign Contacts of the Home Army Headquarters 'Zagroda'. These materials now constitute the core of the Foundation's archival holdings (Minczykowska, 2000; Strzelecka, 2007, p. 114).

Initially, efforts of the Foundation's workers were focused on collecting, preserving, and describing archival materials covering the above mentioned topics, as well as providing access to its holdings, especially for scholars, students, those soldiers whom these holdings concern and their families. Over the years the Foundation organised more educational events, including various conferences and meetings, both scientific and on a scientific theme for the general public. These conferences' topics were, among others: Military service of Polish women during the Second World War, The Home Army, Communist repressions on Poles engaged in pro-independent activity 1939-1956, Kharkiv - Katyn - Tver - Bykivnia. The 70th anniversary of the Katyn massacre, Polish women and pro-independent activity 1918-1939. The 20th anniversary of the Foundation.

The Foundation also organises lectures, lessons and courses for middle school and high school students. Now, the Foundation offers about twenty different topics of lectures and lessons, e.g. How officers of the Polish secret police under Communism murdered their victims?, Animals at the fronts of the Great War and the Second World War, Little soldiers. The role of children during the Second World War, The Polish version of Stalinism. The time of nonsense, and meetings presenting life of General Elżbieta Zawacka, as well as works of the archive - as an example of a contemporary operating community archive (Fundacja Generał Elżbiety Zawackiej, 2017).

Other important parts of the General Elżbieta Zawacka Foundation's works are exhibitions, both set in the buildings of the Foundation and prepared for other institutions to be leased and displayed. The permanent exhibition currently presented in the seat of the Foundation is entitled It's been one hundred years (1909-2009). A few pictures from life of General Elżbieta Zawacka alias Zo. Other topics of exhibitions were, for example: Polish Women's Military Service, A lipsticks and a rifle, Traces of conspiracy in Torun 1939-1945, Human losses in Pomerania 1939-1945. The Foundation worked with various institutions in creating exhibitions; among these institutions are the Institute for National Remembrance, the Polish Army Museum in Warsaw, the Museum of Proindependence Traditions in Łódź (Minczykowska, 2014, pp. 288-290; Strzelecka, 2007, p. 122).

The Elżbieta Zawacka Foundation can boast an unbelievable number of educational events. To sum up, since its formal creation in 1990 the Foundation has organised: over thirty conferences and meetings with around 10.000 participants; more than 1.000 lectures, lessons, and courses, engaging over 22.500 pupils (sic!), mostly as a part of an educational program entitled "Patriotism"; many exhibitions that reached around 25.000 people (Kromp, Minczykowska, 
\& Zawacka-Wakarecy, 2012; Kromp, Minczykowska-Targowska, \& ZawackaWakarecy, 2013, 2014, 2015; Minczykowska, 2010, p. 12; Zawacka-Wakarecy, Minczykowska, \& Kromp, 2011).

\section{CONCLUSION}

Educational activity plays a very important role in the two described community archives, the KARTA Centre Foundation and the Elżbieta Zawacka Foundation. Their numerous educational events reach a very high number of recipients, of various ages. Their educational efforts probably outnumber such actions organised by most other Polish state archives. But it should not be any surprise to anyone who knows the current situation of state archives in Poland - even $90 \%$ of their work is connected to the fact, that these archives are public state offices (Radoń, 2008, p. 10). Community archives perform educational activities because in many cases it is a way to accomplish their mission which lies in much more than only preservation of traces of the past, but also in sharing knowledge of history and strenghtening identities. It might be an interesting theoretical approach to interpret community archives' engagement in educational activities from the point of view of the public principle of archives. According to this general paradigm of archival activity, „everyone on equal terms can use archival materials from all archives in the world, no matter for what reason, and archives are supposed to inform and encourage them to that" (Chorążyczewski, 2014, p. 48). Community archives, like any other historical archives, are an important part of the democratic society of knowledge. I believe it is important to pay proper attention to them, their collections, and activities, also those concerning education in a broad understanding of the term.

\section{REFERENCES}

1. Chorążyczewski, W. (2008). Archiwista przyszłości - edukator i autopromotor w społeczeństwie informacyjnym [The archivist of the future - educator and self-promoter in the information society]. In: J. Porazinski \& K. Stryjkowski (Eds.), Archiwa w nowoczesnym społeczeństwie. Pamiętnik V Zjazdu Archiwistów Polskich Olsztyn 6-8 września 2007 (pp. 45-53). Warszawa: Stowarzyszenie Archiwistów Polskich.

2. Chorążyczewski, W. (2014). Archiwistyka dla początkujących [Archival science for beginners]. Retrieved from https://repozytorium.umk.pl/handle/item/2191.

3. Flinn, A. (2007). Community Histories, Community Archives: Some Opportunities and Challenges. Journal of the Society of Archivists, 28(2), 151-176. doi:10.1080/00379810701611936.

4. Flinn, A. (2011). Archival Activism: Independent and Community-led Archives, Radical Public History and the Heritage Professions. InterActions: UCLA Journal of Education and Information Studies, 7 (2), 1-21.

5. Fundacja Generał Elżbiety Zawackiej. (2017). Fundacja Generał Elżbiety Zawackiej: Prelekcje [General Elżbieta Zawacka Foundation: Lectures]. Retrieved from www.zawacka.pl.

6. Gilliland, A., \& Flinn, A. (2013). Community archives: What are we really talking about. Retrieved from CIRN Prato Community Informatics Conference 2013. http://www.ccnr.infotech.monash.edu.au/assets/docs/prato2013_papers/gilliland_flinn_keynote.pdf. 
7. Gluza, Z. (2006). KARTA - sposób na historię [KARTA - a way to deal with history]. Karta, 50, 104-142.

8. Gluza, Z. (2012a). Archiwa Ośrodka KARTA [Archives of the KARTA Centre]. In: K. Ziętal (Ed.), Archiwistyka społeczna (pp. 27-35). Warszawa: Fundacja Ośrodka KARTA.

9. Gluza, Z. (2012b). Odkrycie KARTY: Niezależna strategia pamięci [Discovering the KARTA: The independent memory strategy]. Warszawa: Ośrodek KARTA, Dom Spotkań z Historią.

10. Kromp, D., Minczykowska, K., \& Zawacka-Wakarecy, D. (2012). Sprawozdanie z działalności Fundacji Generał Elżbiety Zawackiej. Archiwum i Muzeum Pomorskie Armii Krajowej i Wojskowej Służby Polek w Toruniu za rok 2011 [Report on activity of the General Elżbieta Zawacka Foundation: the Pomeranian Archive and Museum of the Home Army and Polish Women's Military Service in Toruń in 2011]. Biuletyn Fundacji Generat Elżbiety Zawackiej, 62, 134-144.

11. Kromp, D., Minczykowska-Targowska, K., \& Zawacka-Wakarecy, D. (2013). Sprawozdanie z działalności Fundacji Generał Elżbiety Zawackiej. Archiwum i Muzeum Pomorskie Armii Krajowej i Wojskowej Służby Polek w Toruniu za rok 2012 [Report on activity of the General Elżbieta Zawacka Foundation: the Pomeranian Archive and Museum of the Home Army and Polish Women's Military Service in Torun in 2012]. Biuletyn Fundacji Generat Elżbiety Zawackiej, 63, 100-110.

12. Kromp, D., Minczykowska-Targowska, K., \& Zawacka-Wakarecy, D. (2014). Sprawozdanie z działalności Fundacji Generał Elżbiety Zawackiej. Archiwum i Muzeum Pomorskie Armii Krajowej i Wojskowej Służby Polek w Toruniu za rok 2013 [Report on activity of the General Elżbieta Zawacka Foundation: the Pomeranian Archive and Museum of the Home Army and Polish Women's Military Service in Torun in 2013]. Biuletyn Fundacji Generał Elżbiety Zawackiej, 64, 84-96.

13. Kromp, D., Minczykowska-Targowska, K., \& Zawacka-Wakarecy, D. (2015). Sprawozdanie z działalności Fundacji Generał Elżbiety Zawackiej. Archiwum i Muzeum Pomorskie Armii Krajowej i Wojskowej Służby Polek w Toruniu za rok 2014 [Report on activity of the General Elżbieta Zawacka Foundation: the Pomeranian Archive and Museum of the Home Army and Polish Women's Military Service in Toruń in 2014]. 65, 127-136.

14. Maciejewska, W. (Ed.). (1974). Polski Słownik Archiwalny [Polish archival dictionary]. Warszawa: Państwowe Wydawnictwo Naukowe.

15. Minczykowska, K. (2000). Wstęp [Introduction]. In: K. Minczykowska (Ed.), Biblioteka Fundacji "Archiwum Pomorskie Armii Krajowej w Toruniu: t. 30. Informator o zbiorach Fundacji "Archiwum Pomorskie Armii Krajowej" (pp. 15-21). Torun: Fundacja “Archiwum Pomorskie Armii Krajowej".

16. Minczykowska, K. (2010). Naukowy i popularyzatorski dorobek Fundacji Generał Elżbiety Zawackiej. Biuletyn Fundacji Generał Elżbiety Zawackiej, 2 (59), 5-14.

17. Minczykowska, K. (2014). Cichociemna: Generat Elżbieta Zawacka "Zo" 1909-2009 [Cichociemna : General Elżbieta Zawacka “Zo” 1909-2009]. Kobiety Niezłomne. Toruń, Warszawa: Fundacja Generał Elżbiety Zawackiej; Oficyna Wydawnicza Rytm.

18. Norgrove, K., Mirchandani, S., \& Goddard, J. (2008). Community Archives Landscape Research: A report for MLA and CADG. Retrieved from http://webarchive.nationalarchives.gov.uk/20111013135435/http:/research.mla.gov.uk/evidence/view-publication. php?pubid=950.

19. Ośrodek KARTA. Historia Bliska - badawczy konkurs historyczny dla młodzieży [The Close History - research competition for the youth]. Retrieved from http://karta.org.pl/ Dzialania/Historia_Bliska_badawcze_konkurs_historyczny_dla_modziezy/37.

20. Pearce-Moses, R. (2005). A glossary of archival and records terminology. Archival fundamentals series: Vol. 2. Chicago: The Society of American Archivists.

21. Radoń, S. (2008). Archiwa polskie - stare i nowe wyzwania [Polish archives - old and new challanges]. In: J. Porazinski \& K. Stryjkowski (Eds.), Archiwa w nowoczesnym społeczeństwie. Pamiętnik V Zjazdu Archiwistów Polskich Olsztyn 6-8 września 2007 (pp. 9-13). Warszawa: Stowarzyszenie Archiwistów Polskich.

22. Rosa, A. (2012). Funkcja edukacyjna archiwów [The educational function of archives]. Warszawa: Naczelna Dyrekcja Archiwów Państwowych. 
23. Strzelecka, M. (2007). Zbiory Fundacji „Archiwum i Muzeum Pomorskie Armii Krajowej oraz Wojskowej Służby Polek” w pracy dydaktycznej i wychowawczej nauczyciela historii [Archival holdings of the Foundation "Pomeranian Archive and Museum of the Home Army and Polish Women Military Service" in a history teacher's didactics and upbringing]. In: S. Roszak \& M. Strzelecka (Eds.), Toruńskie spotkania dydaktyczne: Vol. 4. Muzea i archiwa w edukacji historycznej (pp. 114-123). Toruń: Stowarzyszenie Oświatowców Polskich.

24. Welland, S. (2015). The role, impact and development of community archives in New Zealand: A research paper. Retrieved from: https://repository.openpolytechnic.ac.nz/ bitstream/handle/11072/1752/The\%20role,\% 20impact \% 20and \% 20development \% 20 of $\% 20$ community $\% 20$ archives $\% 20$ in $\% 20 \mathrm{New} \% 20$ Zealand.pdf? sequence $=3$.

25. Zawacka-Wakarecy, D., Minczykowska, K., \& Kromp, D. (2011). Sprawozdanie z działalności Fundacji Generał Elżbiety Zawackiej. Archiwum i Muzeum Pomorskie Armii Krajowej i Wojskowej Służby Polek w Toruniu za rok 2010 [Report on activity of the General Elżbieta Zawacka Foundation: the Pomeranian Archive and Museum of the Home Army and Polish Women's Military Service in Torun in 2010]. Biuletyn Fundacji Generat Elżbiety Zawackiej, (60-61), 95-104.

26. Ziętal, K. (Ed.). (2012). Archiwistyka społeczna [Community archiving]. Warszawa: Fundacja Ośrodka KARTA.

27. Ziętal, K. (2014). Archiwa społeczne w Polsce [Community archives in Poland]. In: W. Chorążyczewski, W. Piasek, \& A. Rosa (Eds.), Toruńskie Konfrontacje Archiwalne: Vol. 4. Nowa archiwistyka. Archiwa $i$ archiwistyka w ponowoczesnym kontekście kulturowym (pp. 71-76). Torun: Wydawnictwo Naukowe Uniwersytetu Mikołaja Kopernika. 